\title{
We do not measure what we aim to measure: Testing Three Measurement Models for Nationalism and Patriotism
}

\author{
Marlene Mußotter $^{1}$ (D)
}

Accepted: 19 July 2021 / Published online: 29 July 2021

(c) The Author(s) 2021

\begin{abstract}
The measurement models for both nationalism and patriotism originally developed by Blank and Schmidt are broadly established. Despite their widespread usage in Germany and beyond, concerns have been voiced about the operationalisation of these nation-related concepts. However, in previous scholarship little attention has been devoted to systematically reviewing the models' validity. This paper's major goal is to contribute substantially to research on operationalising national attitudes by thoroughly examining how both nationalism and patriotism are measured and how valid the predominant measurement models really are. By running a confirmatory factor analysis, three measurement models based on the ISSP data of 2003 are replicated and empirically reviewed. By conducting a single-country analysis, the models are tested for the German case, including the evaluation of measurement invariance for both Eastern and Western Germany. Although the selected measurement models yield satisfying results, the paper identifies considerable shortcomings with regard to the way both nationalism and patriotism are empirically approached. It calls for a reconceptualising of the prevailing concept of pride and thus challenges the predominant operationalisation.
\end{abstract}

Keywords Nationalism $\cdot$ Patriotism $\cdot$ National attachment $\cdot$ Measures $\cdot$ Confirmatory factor analysis

\section{Introduction}

Nationalism and patriotism are fuzzy, yet much used and popular, concepts. While the former is generally understood as an aggressive, supremacist and uncritical attitude towards the nation and is considered to be on the rise (see Bonikowski 2016; Mylonas and Tudor 2021), the latter is termed an enlightened sense of community that takes pride in a commitment to democratic values (Kosterman and Feshbach 1989; Karasawa 2002; Blank and Schmidt 2003; Davidov 2009; Satherly et al. 2019; Huddy et al. 2021). The implication is that nationalism has to be curtailed (e.g., Mounk 2018), whereas patriotism is promoted as

Marlene Mußotter

marlene.mussotter@uni-passau.de

1 Professorship of Methods of Empirical Social Sciences, University of Passau, Dr.

Hans-Kapfinger-Straße 14b, 94032 Passau, Germany 
a civic virtue (MacIntyre 1995; Ben-Porath 2007; Costa 2020) and as a socially desirable goal worth striving for.

To date, there have been remarkable approaches to measuring both concepts and to empirically assessing their impacts. For instance, a dominant strand of empirical research explores relationships such as that between nationalism, patriotism and anti-immigration attitudes (de Figueiredo and Elkins 2003; Wagner et al. 2012; Heinrich 2020; Simonsen and Bonikowksi 2020). In addition, much valuable work has been done regarding the interrelation between patriotism, national identity and political attitudes (e.g., Huddy and Khatib 2007), between patriotism, nationalism and national identity (e.g., Li and Brewer 2004; Hanson and O'Dwyer 2019) and between patriotism, nationalism and internationalism (e.g., Kosterman and Feshbach 1989; Karasawa 2002). Despite the rich field of empirical research on both nationalism and patriotism, the current discourse is flawed by " $[\ldots] a$ variety of scales and concepts that is characterised by conflicting and contradictory terminology and measurement" (Huddy 2016: 18). Put differently, a number of measures have been applied, but the question of their validity, i.e., the way the conceptual level is translated into the measurement level, has received comparatively little attention in empirical scholarship. Concerns about the operationalisation of both nationalism and patriotism have only been raised by very few scholars, such as Bonikowski (2016), who criticised the current measures, without going into detail, for being too reductive. From a more qualitative perspective, comprehension difficulties have been detected concerning the pride items primarily used to measure nationalism and patriotism in the case of Austria (Latcheva 2011). However, existing accounts have missed reviewing the predominant models, or critically reflecting on their validity in a systematic fashion.

Taking this research gap as a point of departure, this paper distinguishes itself by taking a step back and by explicitly asking how nationalism and patriotism are measured and if we really measure what we aim to measure. In this sense, the concept of pride, which has been predominantly used to operationalise both nationalism and patriotism, is also taken into account. Running a confirmatory factor analysis, three measurement models used by Davidov (2009), Fleiß et al. (2009) and Ariely (2011), all standing in the research tradition of Blank and Schmidt (2003) and exemplifying the state of research, are systematically compared and reviewed. Addressing the empirical muddiness in current scholarship, attention is shifted to the way nationalism and patriotism are conceptualised and translated into measurement instruments, i.e., the way the empirical level is reflected in the numerical level. In this sense, light is cast on the models' content validity, i.e., the extent to which the measurements capture the core conceptual dimensions (e.g., Bollen 1989; De Vellis 2017).

By conducting a single-country analysis, the three models are tested for the German case, which is of special interest mainly for two reasons. First, there is broad agreement that Germans have a comparatively complicated relationship with their nation, resulting in the contested nature of national attitudes such as nationalism and patriotism (Bergsieker 2010; Miller-Idriss and Rothenberg 2012; Meitinger 2018; Assmann 2020). Second, there is no doubt that decades of post-war division have affected not only citizens' attitudes toward their nation, but also national cohesion in general. Regarding the historical experiences and national narratives in the former German Democratic Republic (GDR), differences between the reunified parts of Germany have been taken into account (e.g., Palmowski 2008; Giebler et al. 2020). For this reason, the models are also tested for measurement invariance, in order to investigate how valid they are for both regions.

This paper is organised into three sections. First, it addresses how both nationalism and patriotism are defined in the literature, followed by a brief discourse on pride as a groupbased emotion. Then, a confirmatory factor analysis (CFA) for the three measurement 
models is conducted. Lastly, the paper discusses the empirical results and closes with two major remarks aimed at improving future research on operationalising these national attitudes, which are currently gaining in importance.

\section{Concepts}

Zooming in on the academic discourse on national attitudes, one is faced with a plethora of conceptual distinctions. On the one hand, one counterposes different forms of nationalism, such as ethnic and civic nationalism (e.g., Ignatieff 1993), Western and Eastern nationalism (Kohn 1944), or ardent, disengaged, restrictive and creedal nationalism (Bonikowski and Di Maggio 2016). On the other hand, one contrasts diverse forms of patriotism, such as military vs. civic patriotism (Curti 1946), genuine vs. pseudo-patriotism (Levinson et al. 1950), constructive vs. blind patriotism (e.g., Schatz et al. 1999), uncritical vs. critical patriotism (Miller and Ali 2014), extreme vs. moderate patriotism (Nathanson 2020), as well as symbolic patriotism (Huddy and Khatib 2007), robust patriotism, deflated patriotism, or ethical patriotism (Primoratz 2017). This paper, however, focuses on the binary distinction between nationalism and patriotism, since the scholars referenced here adhere to this established terminology (for critical remarks on this dichotomy, see Brubaker 2004; Bonikowksi 2016; Satherly et al. 2019).

Overall, nationalism rests on three fundamental premises. First, it is basically associated with the view whereby the world is categorised into nations - in social, cultural and political terms (e.g., Billig 1995; for further discussion, see Wimmer and Glick Schiller 2002 on methodological nationalism). Second, it is assumed that individuals must feel exclusively attached to one particular nation (Dekker et al. 2003; Brubaker 2020). Third, at its core is the belief that nationalistic attitudes emanate from authoritarian thought patterns (Blank and Schmidt 2003; Wessel 2019).

A dominant strand of empirical research defines nationalism as the idealisation of one's nation (Kosterman and Feshbach 1989; Blank and Schmidt 2003; Bonikowski 2016), i.e., the nation is seen as the highest (secular) authority people have to subordinate themselves to (e.g., Langewiesche 2002). Consequently, an unreflective allegiance to the nation, under any circumstances, is a constitutive element (for a more differentiated view, see Blank and Schmidt 2003). In this light, nationalists are assumed to support their nation whether it is right or wrong (e.g., de Figueiredo and Elkins 2003). Given these associations, nationalism is equated with feelings of superiority over other nations and with a desire for dominance (Kosterman and Feshbach 1989; Heinrich 2020; Osborne et al. 2017; for a more differentiated view, see e.g., Mylonas and Tudor 2021). Based on "[...] downward comparisons with other nations", it is argued that one's nation and thus one's people, are superior to others (Kosterman and Feshbach 1989: 271). This position, perceived as undisputed, is fostered by comparisons with other nations that are regularly seen as weak and less competitive (de Figueiredo and Elkins 2003). Notably, nationalism revolves not only around feelings of superiority, but also around notions of competitiveness. The persistent "struggle for power" among nations is thus a central aspect (Hroch 2020: 8; for an opposing view, see e.g., Bonikowski 2016). Further, nationalism is associated with a feeling of "chosen-ness" (Billig 1995; Tamir 2019) and thus characterised by a "narrative of exceptionalism" (Feinstein and Bonikowski 2021). As a result, a leadership claim. as well as a mission claim, are derived. Nationalists feel entitled to impose their supposedly superior national morale on other nations and to seek to expand their nation's influence abroad (de Lamater et al. 
1969; Kosterman and Feshbach 1989; Blank and Schmidt 2003). Concerning the conception of a people, nationalism is characterised by an imperative of homogeneity (Dekker et al. 2003; Wessel 2019) indicating that the people are primarily regarded as an organic community bound together by one ethnicity, one culture and one religion. Notably, a positive effect of social dominance orientation (SDO) on nationalism has been corroborated in a wide array of studies (Sidanius et al. 1997; Molina et al. 2015; Osborne et al. 2017) highlighting the impact of the most dominant ethnic group in this matter. Consistently, the literature on nationalism underlines a rather exclusionary conception of the nation based on ethnic membership criteria (e.g.,Bonikowski 2016; Molina and Preddie 2020). Further, nationalism is marked by a narrative of threat (Schatz et al. 1999; Fukuyama 2018; Wessel 2019). Since the national we is (constantly) seen as threatened by a foreign them, it is argued that nationalists feel the need to defend their nation against any out-groups. Consistent with these exclusionary notions, as well as with the narrative described, the empirical findings indicating that nationalism reinforces anti-immigration attitudes have been corroborated by many studies (Blank and Schmidt 2003; de Figueiredo and Elkins 2003; Wagner et al. 2012; Molina and Preddie 2020). This evidence substantiates the argument that sees nationalism as the driving force for conflicts and wars (notably Wimmer 2018).

However, when examining nationalism's complexity, one needs to bear in mind its Janus-faced character. Considered a driving force behind the number of movements for independence in the eighteenth century (e.g., Mylonas and Tudor 2021), nationalism is also seen as an ideology of integration, effectively uniting collectives (e.g., Langewiesche 2002). Proponents of a "liberal nationalism", such as Yael Tamir (1990; 2019) and David Miller (1995; see also Gustavsson and Miller 2019), stress the latter aspect, asserting that nationalism has not only a destructive, but also a somewhat cohesive dimension, which scholars tend to overlook (Tamir 2019). Criticising the predominant interpretation of nationalism as chauvinistic, irrational and bellicose, adherents of liberal nationalism offer a more positive interpretation, reconciling nationalism and liberalism (for a critique, see Ariely 2011). In this sense, nationalism is assumed to fulfil basic human needs such as the "need to belong" or the desire "[...] to enjoy a sense of stability and cross-generational continuity" (ibid: 155). In addition, the importance of pre-political ties such as a common culture or a collective memory in constituting national unity is emphasised (Tamir 2019).

Although a universally applicable definition of patriotism is hard to find in scholarly discourse, there are a few core features on which most scholars agree. Generally, patriotism is termed as "love of country" (Schildkraut 2014: 454, see also Primoratz 2017; Gilbert and Garcia 2020) and associated with "[...] feelings of affective attachment to country" (Schatz et al.1999:153; see also Kosterman and Feshbach 1989; Osborne et al. 2017). ${ }^{1}$ In this sense, it is unequivocally argued that patriots feel highly devoted to their homeland (notably Nathanson 2020).

Apart from these core emotional features, another strand of literature consistently defines patriotism as an enlightened sense of community that takes pride in a commitment to democratic and humanist values (Kosterman and Feshbach 1989; Satherly et al. 2019; Hanson and O'Dwyer 2019). Understood as a critical and constructive attitude towards the nation (Blank and Schmidt 2003; Sapountzis 2008; Kronenberg 2013), patriotism is promoted as a civic virtue (e.g., MacIntyre 1995; Kronenberg 2013; Costa 2020) and as a

\footnotetext{
1 Given the definition by de Lamater et al. (1969: 320) of nationalism as an "[...] individual's emotional attachment to his nation [...] which leads him to desire more power for it", the conceptual conflation of nationalism and patriotism becomes evident at this point.
} 
socially desirable goal worth striving for. From this point of view, patriotism appears as a civic counterpart not based on any downward comparisons, but rather self-referential (de Figueiredo and Elkins 2003; see also Mummendy et al. 2001). In the literature, there is broad agreement that patriotism implies respect and esteem for other nations and rejects any form of dominance or superiority (for a critical remark, see Mader 2016). Compared with nationalism, the nation is assumed to be bound not by ethnic, but by civic criteria such as loyalty to political institutions. In this sense, patriotism is associated with a more heterogeneous notion of the people and with a rather broad and inclusive definition of membership and belonging (Blank and Schmidt 2003; Kronenberg 2013; Huddy et al. 2021). Given these associations, a wide array of studies have shed empirical light on the negative relationship between patriotism and anti-immigration attitudes (Blank and Schmidt 2003; Wagner et al. 2012; Heinrich 2020; for an opposing view, see Cohrs et al. 2004).

Concerning this paper's case study, it is important to address the particular debate on patriotism in Germany. Originally promoted by Sternberger (1990), Habermas and Müller have been advocating a “constitutional patriotism” (Habermas 1992; Müller 2010). Resting on the assumption that cultural inclusiveness and national identity are hard to reconcile (for an opposing view, see the work of Laborde (2002) on civic patriotism or of Tamir (2019) on liberal nationalism), they claim that any form of national affiliation can only be regarded in political terms (Müller 2010). In this sense, constitutional patriotism advocates a specific form of citizenship that is mainly defined by "[...] universalistic principles and procedures of the liberal democracy" (ibid: 10). Given this normative framework, a common political culture based on a shared democratic consensus (Habermas 1992) replaces the nation as the primary point of reference. Dissenting from any kind of national attachment, this kind of patriotism is marked by a primarily cosmopolitan interpretation of citizenship (for a further discussion, see Laborde and Erez (2020) on cosmopolitan patriotism). Placing emphasis solely on democratic values, constitutional patriotism is assumed to successfully bind together diverse societies (e.g., Ingram 1996). Given these associations, however, it is open to debate if this kind of patriotism is rather a form of democratic attachment than a national attitude.

\subsection{Pride as a group-based emotion}

Although pride is not explicitly stated in the literature as a crucial prerequisite for either nationalism or patriotism, the predominant measurement models and thus the three models that this paper reviews, measure both nationalism and patriotism by means of this concept. As a result, pride items such as pride in the way democracy works are applied without further explanation. Given this consensus, it is worth briefly addressing the academic discourse on this concept in order to better assess how the conceptual level is translated into the measurement level.

Overall, pride is understood as a self-conscious emotion that people experience when reaching or surpassing "important identity goals" (Tracy et al. 2020: 53). Evidently, identity and pride are closely interlinked, yet to be distinguished (e.g., Ha and Hang 2015; Meitinger 2018; Choi et al. 2021). In research on pride, one differentiates between different kinds of pride, the most prevalent difference being seen as between hubristic and authentic pride (Tracy and Robins 2007; Tracy et al. 2020). While the former is linked to feelings of arrogance and superiority, the latter is associated with feelings of achievement and high self-esteem (Tracy and Robins 2007). Strikingly, only a very few scholars, such as Ha and Jang (2015), have linked this binary distinction with national attitudes, asserting 
that patriotism is based on authentic pride, whereas nationalism is associated with hubristic pride. However, they fail to provide a thorough argument for their claim. In terms of national pride, one distinguishes between a more general kind described as normative national pride and a more domain-specific kind described as grounded national pride (Fabrykant and Magun 2015). In addition, Hjerm (2003) counterposes these to a national political pride that is linked to civic criteria such as pride in political institutions and a national cultural pride that is primarily associated with pride in one's nation's history.

Drawing on the intergroup emotion theory (Smith and Mackie 2015), national pride is regarded as a group-based emotion. Contrasting individual-level with group-level emotions, this theory holds that group-based emotions such as pride are primarily activated "[...] by events that affect groups with which people identify even if the events do not directly affect the individual" (ibid: 350). For instance, people can take pride in a national sports team and are likely to feel anxious if their nation is threatened. Further, groupbased emotions such as pride have a large impact on the behaviour of the social group concerned. Notably, scholarship on pride has shown evidence that pride is largely based on social comparisons (van Osch et al. 2018). In this sense, among others, Wimmer (2018; see also Bergsieker 2010; Sidanius et al. 1997) has shown that the degree of pride a citizen expresses towards her/his country is highly dependent on his/her status in society: if one has a comparatively high position, one is more likely to be proud of one's nation.

\section{Data and Method}

Generally, confirmatory factor analysis (CFA) is regarded as an established method for investigating the unidimensionality and validity of a scale (Harrington 2009; Brown 2015; Grimaccia and Naccaroto 2020). In contrast to exploratory factor analysis (EFA), CFA is mainly theory-driven, i.e., the measurement model is based on concrete assumptions that researchers hold about relationships between the items concerned and the factors they intend to measure. In this sense, the goal is to test if the factor structure previously suggested (in many cases) by an EFA can be empirically confirmed and preliminarily verified. In doing this, CFA primarily serves to investigate how far the model fits the data and how valid the model really is. Since this paper compares how Davidov (2009), Fleiß et al. (2009) and Ariely (2011) measure both nationalism and patriotism with the ISSP data of 2003 and reviews their models' validity, i.e., how far the conceptual level is translated into the measurement level, CFA is expected to serve as an appropriate tool. Drawing on conventional measurement standards (see Brown 2015), a model is considered valid a) if its fit-indices fulfil the required cut-off criteria, b) if the model is not flawed by any significant poor fits suggested in the modification indices and c) if the model is marked by high factor validity, i.e., if items display standardised factor loadings of over 0.55 and reflect well the factor concerned. Generally, these factor loadings are regarded as the correlation between the indicators and the factor they load onto. Conducting a CFA with Mplus (Version 8), the WLSMV estimator was used since this is the most accurate estimator for testing models that contain ordinal data (e.g., Brown 2015; Liu et al. 2017; DiStefano et al. 2019). ${ }^{2}$

\footnotetext{
${ }^{2}$ At this point, it is worth mentioning that none of the scholars referenced used WLMSV; they ran their models with an estimator such as maximum likelihood (Davidov 2009).
} 
Concerning patriotism, it is noteworthy that all three models measure this concept with the same three pride indicators, namely pride in the way democracy works, pride in the social security system and pride in the fair and equal treatment of all groups in society. All items were measured on a unipolar scale ranging from 1 to $4(1=$ very proud, $4=$ not proud at all).

In contrast, nationalism was measured quite differently. As displayed in Table 1, Ariely, as the first scholar operationalising liberal nationalism, used two pride indicators measured on a scale from 1 to $4(1=$ very proud, $4=$ not proud at all), namely pride in arts and literature and pride in the nation's history. He contends that "[...] these items reflect the liberal nationalist idea of a common cultural identity grounded in a specific history and culture" (Ariely 2011:302).

Fleiß et al. (2009), conducting an exploratory factor analysis (EFA) for the case of Western Germany, operationalised nationalism through seven items. Three of these were related to pride: pride in the nation's history, pride in the nation's armed forces and pride in the nation's success in sports (see Table 2). All these items ranged on a scale from 1 to 4 (1= very proud, $4=$ not proud at all). Fleiß et al. (2009: 419) additionally included the factor "general pride in the nation". Contrary to this factor's name, it did not adhere to the concept of pride and referred to belief in the superiority of one's nation and uncritical loyalty to it. As shown in Table 2, items such as "People should support their country even if the country is in the wrong" or "Generally, my country is better than most other countries" were part of this scale. These items could assume values from 1 to 5 ( $1=$ agree strongly, 5 $=$ disagree strongly).

As depicted in Table 3, Davidov measured nationalism with two items exclusively targeting the superiority of one's nation and ranging on a scale from 1 to 5 ( $1=$ agree strongly, $5=$ disagree strongly). ${ }^{3}$ By comparison with other scholars, this model did not adhere to any pride item batteries.

Given that these two items are also used by Fleiß et al. and that both studies apply the same items for patriotism, Davidov's model can be considered as nested under the model used by Fleiß et al. (Brown 2015).

The model test is applied for the German ISSP data from 2003 and encompasses Germany as a whole, as in Davidov's (2009) study. By contrast, Fleiß et al. (2009) and Ariely (2011) focused only on the Western part of Germany in their studies. In total, 1,287 Germans participated in the survey, $66.05 \%$ of whom came from the Western and $33.95 \%$ from the Eastern part. With respect to gender distribution, $50.43 \%$ of participants were male and $49.57 \%$ were female. The respondents' mean age was 47 years $(\mathrm{SD}=17.090)$. Most of the respondents had a rather low level of education (over $39 \%$ had completed lower secondary school and over $32 \%$ middle school), while only $8 \%$ had completed university.

\footnotetext{
3 Strikingly, these items have also been used in the US for measuring both nationalism (e.g. Huddy and Khatib 2007; Hanson and O'Dwer 2019) and chauvinism (e.g. Citrin et al. 2001; Mader 2016; Feinstein and Bonikowksi 2021). Evidently, the distinction between nationalism and chauvinism remains open to debate.
} 


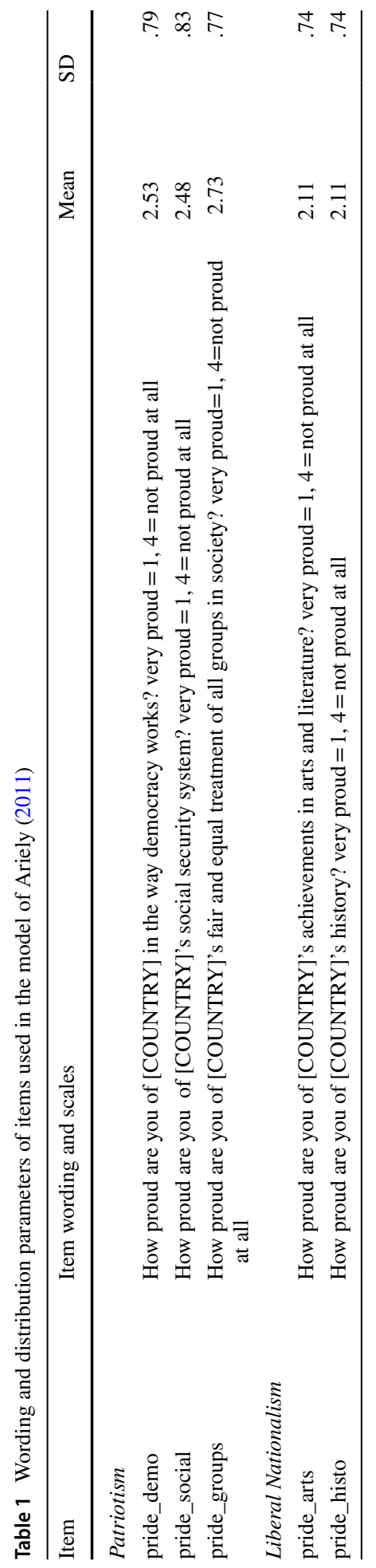




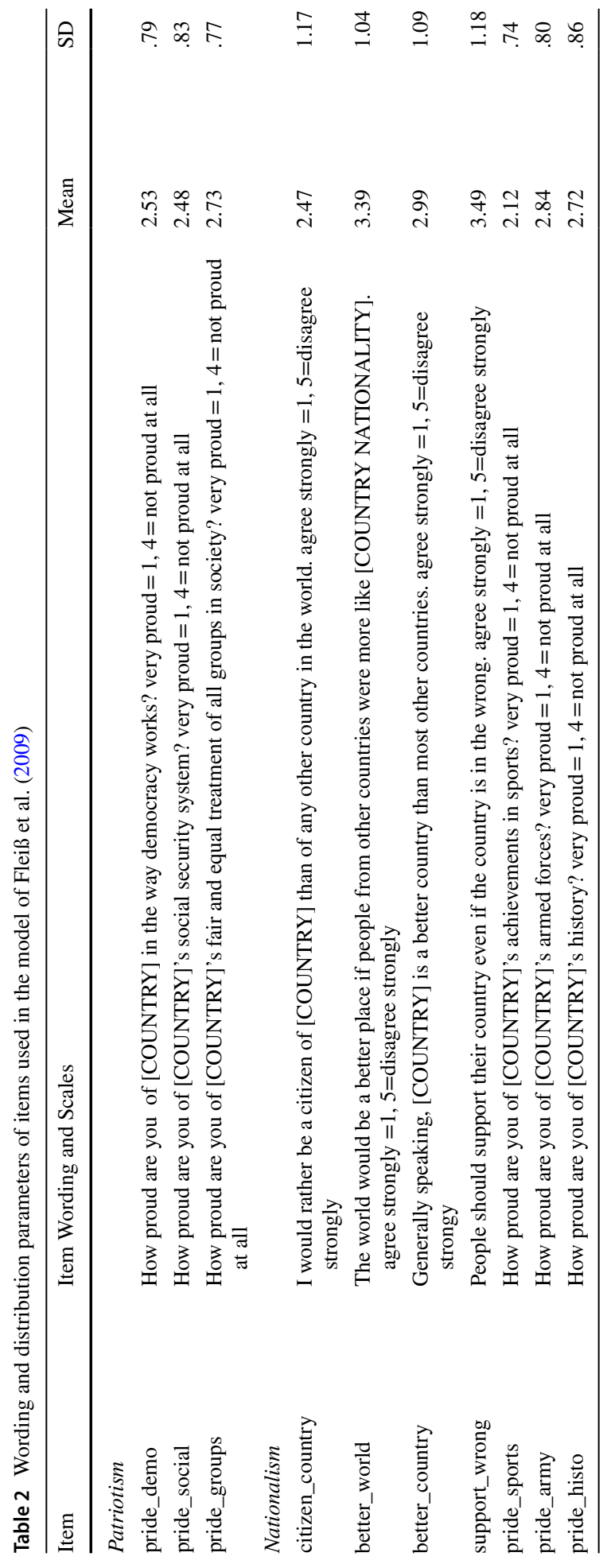




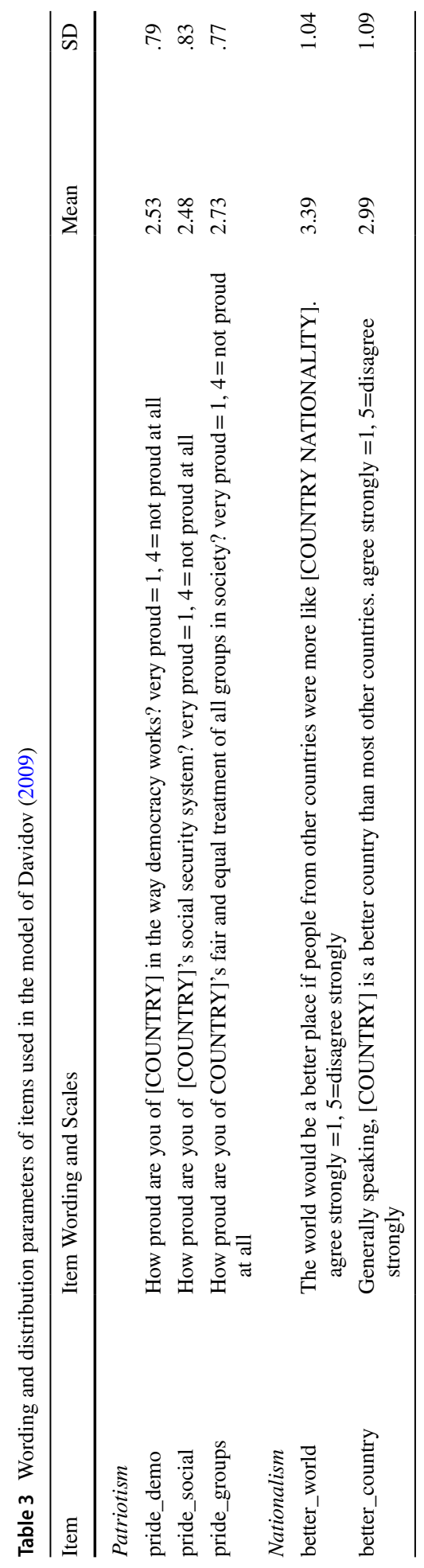


Table 4 Fit measures of all measurement models

\begin{tabular}{|c|c|c|c|c|c|c|c|c|c|}
\hline & $\chi^{2}$ & df & RMSEA & $90 \%$ C.I & & $\begin{array}{l}\mathrm{p} \text { for } \\
\text { RMSEA }\end{array}$ & CFI & TLI & SRMR \\
\hline Ariely & 19.213 & 4 & .064 & $\begin{array}{l}.037 \\
.094\end{array}$ & & .177 & .985 & .963 & .019 \\
\hline Fleiß et al. & 129.347 & 32 & .061 & $\begin{array}{l}.050 \\
.072\end{array}$ & & .047 & .956 & .939 & .037 \\
\hline Davidov & 15.734 & 5 & .041 & .065 & .019 & .706 & .990 & .980 & .020 \\
\hline
\end{tabular}

Table 5 Measurement models with completely standardised factor loadings for patriotism

\begin{tabular}{llll}
\hline & Ariely & Fleiß et al. & Davidov \\
\hline Patriotism & & & \\
pride_demo & .675 & .660 & .706 \\
pride_social & .761 & .640 & .684 \\
pride_groups & .633 & .667 & .670 \\
\hline
\end{tabular}

\section{Empirical results}

Overall, drawing on the pertinent cut-off criteria, the three models yielded reasonable fits (See Table 4). ${ }^{4}$ The adjusted Davidov model showed the best fit of all (Chi $=15.734$, $\mathrm{df}=5, \mathrm{RMSEA}=0.041, \mathrm{SRMR}=0.020, \mathrm{CFI}=0.990, \mathrm{TLI}=0.980)$. The Ariely model also provided a very adequate fit $(\mathrm{Chi}=19.213, \mathrm{df}=4, \mathrm{RMSEA}=0.064$, SRMR $=0.019$, $\mathrm{CFI}=0.985$, TLI $=0.963$ ). The Fleiß model was first run with one nationalism factor, but this fitted poorly and had to be rejected (Chi $=447.709$, df $=34$, RMSEA $=0.122$, $\mathrm{SRMR}=0.070, \mathrm{CFI}=0.851$, TLI $=0.755)$. When estimating the model with two nationalism factors (one referring to a general pride not adhering to pride items, while the other consisted of pride items only), the fit was much better $(\mathrm{Chi}=129.347, \mathrm{df}=32$, RMSEA $=0.061, \mathrm{SRMR}=0.037, \mathrm{CFI}=0.956, \mathrm{TLI}=0.939$ ).

In terms of patriotism, the items' standardised factor loadings in all models were greater than 0.60 (see Table 5) and were statistically significant.

Since nationalism was operationalised differently in each of the three models, their items' statistical significance also differed, as shown in Table 6. When reviewing the three models, one problem occurred: the Davidov model demonstrated a so-called "Heywood case" (Brown 2015:162), indicating a negative error variance with regard to the better country item. Like Davidov (2009), the variable concerned was constrained to zero in order to handle this case. The second variable displayed a factor loading of 0.53 and was statistically significant.

When testing the Ariely model, the item referring to pride in history accounted for a rather poor factor loading of 0.44 . In contrast, the second item - pride in the nation's achievements in arts and literature - yielded a reasonable factor loading of 0.65 and was highly significant.

With respect to the model of Fleiß et al., the factor loadings of the items addressing the general pride factor (NAT 1) ranged from 0.42 to 0.76 . Apart from one exception, all

\footnotetext{
${ }^{4}$ Drawing on Hu and Bentler (1999; see also Brown 2015), a model is seen as valid if a) the SRMR is close to 0.08 or lower, b) the RMSEA is close to 0.06 or lower and c) the CFI and TLI are close to 0.95 or greater.
} 
Table 6 Measurement models with completely standardised factor loadings for nationalism

\begin{tabular}{llll}
\hline & Ariely & Fleiß et al. & Davidov \\
\hline Nationalism & & & \\
pride_arts & .651 & .597 & \\
pride_histo & .443 & .427 & .531 \\
citizen_country & & .559 & 1.00 \\
support_wrong & & .762 & .750 \\
better_world & & .574 & .708 \\
better_country & & & \\
pride_sports & & & \\
pride_army & & & \\
\hline
\end{tabular}

items were statistically significant and thus reflected the factor very well. The items targeting the nation's superiority displayed the highest standardised factor loadings of over 0.70 . Concerning the second nationalism factor (NAT 2), the pride items' standardised factor loadings ranged from 0.57 to 0.70 and were all statistically significant. Strikingly, pride in the armed forces loaded the highest on that factor. Further, a correlation between the two nationalism factors of over 0.40 was evidenced.

In line with previous studies (e.g., Latcheva 2011; Satherly et al. 2019; Wagner et al. 2012; Huddy et al. 2021), a relatively high factor correlation between patriotism and nationalism of over 0.57 was found in the Ariely model, which might originate from the pride item batteries used for both patriotism and liberal nationalism. In a similar vein, the model of Fleiß et al. also showed a factor correlation of 0.44 between patriotism and the second factor of nationalism (NAT 2), consisting of pride items only. Although both factors evidently shared a considerable amount of variance, their factor correlation was below the threshold of 0.85 (Brown 2015: 28) and these did not need to be converged to one single factor. In contrast, the Davidov model displayed a standardised factor correlation of only 0.19 and the model of Fleiß et al. a correlation between the first nationalism factor (NAT 1) and patriotism of only 0.22 . The findings in these cases might result from the fact that not only pride items, but also items not adhering to the concept of pride were applied to the measurement of both nationalism and patriotism.

\subsection{Validity across Western and Eastern Germany: testing measurement invariance}

Prior to evaluating measurement invariance, a CFA with WLSMV as estimator was conducted in Mplus for each model, investigating both groups separately. Overall, as shown in Table 7, except for the model of Fleiß et al., all the models yielded a reasonable fit.

In order to examine the validity of the models across different groups, measurement invariance needs to be tested. Generally, one distinguishes between three different kinds of invariance: configural, metric and scalar invariance. If all kinds of variance are supported, full invariance is given. ${ }^{5}$ According to Davidov, configural invariance is fulfilled if "[...]

\footnotetext{
5 However, since scalar variance, as the most rigid form, is difficult to achieve, calls for alternative and thus less strict approaches, i.e., approximate rather than exact measurement invariance, have been voiced (e.g., Davidov et al. 2015; Cieciuch et al. 2018).
} 
Table 7 Fit measures of all measurement models for Western and Eastern Germany

\begin{tabular}{|c|c|c|c|c|c|c|c|c|}
\hline & $\chi^{2}$ & $\mathrm{df}$ & RMSEA & $\mathrm{p}$ for RMSEA & $90 \%$ C.I & CFI & TLI & SRMR \\
\hline \multicolumn{9}{|l|}{ Ariely } \\
\hline Western Germany & 11.848 & 3 & .060 & .271 & $\begin{array}{l}.027 \\
.097\end{array}$ & .986 & .953 & .017 \\
\hline Eastern Germany & 8.668 & 4 & .052 & .399 & $\begin{array}{l}.000 \\
.100\end{array}$ & .990 & .974 & .023 \\
\hline \multicolumn{9}{|l|}{ Fleiß et al. } \\
\hline Western Germany & 103.966 & 32 & .051 & .394 & $\begin{array}{l}.041 \\
.063\end{array}$ & .941 & .918 & .037 \\
\hline Eastern Germany & 63.919 & 32 & .048 & .561 & $\begin{array}{l}.030 \\
.065\end{array}$ & .959 & .943 & .042 \\
\hline \multicolumn{9}{|l|}{ Davidov } \\
\hline Western Germany & 15.545 & 5 & .050 & .448 & $\begin{array}{l}.023 \\
.079\end{array}$ & .982 & .963 & .025 \\
\hline Eastern Germany & 9.589 & 5 & .046 & .497 & $\begin{array}{l}.000 \\
.089\end{array}$ & .988 & .976 & .027 \\
\hline
\end{tabular}

a) a single model specifying the items that measure each construct fits the data, b) all item loadings are substantial and significant and c) the correlations between the factors are less than one". It serves as the baseline model and indicates that the constructs are measured by the same indicators in all groups. However, in order to examine if both Western and Eastern Germans have an equal notion of nationalism and patriotism, one needs to test for metric invariance. This level of invariance is supported if the model fit is not considerably worse than that of the configural model (Cieciuch et al. 2018). In order to compare the means between the respective constructs, a scalar invariance needs to be held, which is corroborated if the respective model fit is reasonable and does not demonstrate a considerably worse fit compared with the metric fit (Davidov 2009). When comparing the fits between the respective models, one draws on the pertinent cut-off criteria established by Chen (2007:501), who suggested that model fits should not display a change greater than "[...] -0.010 in CFI supplemented by a change greater than 0.015 in RMSEA or a change greater than 0.030 in SRMR [or when comparing a scalar to a metric model] a change in SRMR greater than 0.010".

Regarding the Ariely model, the configural invariance model displayed a reasonable fit and can thus be seen as fulfilled (RMSEA $=0.072, \mathrm{SRMR}=0.024, \mathrm{CFI}=0.981$ ). As shown in Table 8, the fit of the metric invariance model was satisfying, but worse than that of the configural model (RMSEA $=0.085, \mathrm{SRMR}=0.030, \mathrm{CFI}=0.963$ ). Drawing on Chen (2007), partial metric variance was supported, which means that both groups have not the same but a very similar understanding of national attitudes. Scalar invariance was not evidenced, since the fit of the scalar model was worse than the metric (RMSEA $=0.076$, $\mathrm{SRMR}=0.035, \mathrm{CFI}=0.949$ ). Consequently, a solid empirical fundament for comparing means between the two factors is not provided.

Regarding Davidov, the configural invariance model yielded a reasonable fit $(\mathrm{RMSEA}=0.059, \mathrm{SRMR}=0.033, \mathrm{CFI}=0.977)$. Therefore, this level of invariance can be considered as having been met. The metric invariance model was found to be a satisfying, but a slightly worse fit compared with the configural model (RMSEA $=0.067$, $\mathrm{SRMR}=0.051, \mathrm{CFI}=0.961$ ). For this reason, metric invariance can be regarded as 
Table 8 MGCFA: Fit measures of the invariance test for all measurement models

\begin{tabular}{llllllllll}
\hline & $\chi 2$ & df & RMSEA & $\Delta$ RMSEA & SRMR & $\Delta$ SRMR & CFI & $\Delta$ CFI & TLI \\
\hline Ariely & & & & & & & & & \\
Configural invariance & 27.214 & 8 & .072 & & .024 & & .981 & & .952 \\
Metric invariance & 47.819 & 11 & .085 & .013 & .030 & .006 & .963 & .018 & .932 \\
Scalar invariance & 69.808 & 19 & .076 & .009 & .035 & .005 & .949 & .014 & .946 \\
Fleiß et al. & & & & & & & & & \\
Configural invariance & 349.866 & 68 & .101 & & .076 & & .771 & & .698 \\
Metric invariance & 383.294 & 76 & .099 & .002 & .087 & .011 & .751 & .020 & .705 \\
Scalar invariance & 408.264 & 84 & .097 & .002 & .090 & .003 & .737 & .014 & .718 \\
Davidov & & & & & & & & & \\
Configural invariance & 26.809 & 10 & .059 & & .033 & & .977 & & .954 \\
Metric invariance & 41.655 & 13 & .067 & .008 & .051 & .018 & .961 & .016 & .940 \\
Scalar invariance & 47.455 & 16 & .063 & .004 & .060 & .009 & .957 & .004 & .946 \\
\hline
\end{tabular}

fulfilled. The fit of the scalar invariance model was acceptable and did not considerably degrade the fit of the previous solution. Therefore, this allows for a comparison of means between the two factors across Eastern and Western Germany (RMSEA $=0.063$, $\mathrm{SRMR}=0.060, \mathrm{CFI}=0.957$ ).

Regarding Fleiß et al., the configural invariance model displayed a poor fit (RMSEA $=0.101, \mathrm{SRMR}=0.076, \mathrm{CFI}=0.771)$. The metric invariance model also had to be rejected $(\mathrm{RMSEA}=0.099, \mathrm{SRMR}=0.087, \mathrm{CFI}=0.751)$. As a result, this model did not allow for any meaningful group comparisons between Eastern and Western Germany.

\section{Discussion}

The results show that there is a broad consensus concerning the operationalisation of patriotism by means of pride. In contrast, except for some similarities, different measurements have been applied to nationalism. In terms of validity, the models generally displayed reasonable fits and their factor

validity, i.e., the degree to which the items reflect the factor, was satisfying. However, when critically reflecting on the way the empirical level is translated into the numerical level, i.e., the way patriotism and nationalism are broadly defined in the literature and operationalised, a few distinct shortcomings involved in these measurements are worth illuminating.

Concerning patriotism, first, the models indicate that this concept is primarily attached to a sphere of (democratic) rationality and measures constitutional patriotism in the Habermasian sense. However, given the broad consensus on patriotism as "[...] positive identification with and affective attachment toward the country [...]”" (Schatz et al.1999: 153; see also Citrin et al. 2001) and "love of country" (Schildkraut 2014: 454), the models failed to reflect emotional attachment to the nation and thus the emotional core of the concept. In addition, looking at the definition of patriotism more closely, the distinction between national identity and patriotism was not as clear as had been assumed, but rather blurred. Although scholars tend to regard national identity as the overarching concept of both 
nationalism and patriotism (e.g., Blank and Schmidt 2003; Hanson and O'Dwyer 2019), one is faced with a conceptual muddiness which is also mirrored in empirical terms. Notably, items such as "I love my country" were applied to measuring both national identity (e.g., Blank 2002; Molina et al. 2015) and patriotism (e.g., Kosterman and Feshbach 1989; Karasawa 2002; Molina and Preddie 2020). This was surprising, in so far as identification with the nation is obviously to be distinguished from love of country and the will to make sacrifices for it. Put differently, people can identify with the nation without necessarily feeling a strong emotional attachment to it. In future research, this relationship deserves further scrutiny in order to disentangle the conflation of the two concepts.

Second, the existing measurements are marked by a highly vague character in terms of validity (De Vellis 2017). Items such as "proud of the way different groups are fairly treated" make too much room for very different kinds of interpretations. Given the variety of religious, ethnic or political groups in Germany and also abroad, it remains unclear which types of groups are targeted or who actually counts as a group. Besides, it is open to debate if this item properly taps the concept's core features or reflects the high devotion to democratic values. Hence, it does not clearly assess the protection of minorities and thus targets a basic democratic principle that constitutional patriots are assumed to endorse. This wariness is also exemplified by other items such as "proud of the way the democracy works". On the one hand, this item targets the functionality and stability of the democratic system, but fails to assess the mere attachment to democratic principles associated with constitutional patriots. On the other hand, certainly, there are citizens who are in favour of the democratic system, or even content with the current state of democracy in Germany, but would not necessarily express pride in it. For instance, recently it has been evidenced that German citizens do support democracy in general, but are discontented with democratic procedures and the way these work in their country (Busch 2020). In this light, they would score rather low on this item and might appear to be unpatriotic. However, the predominant measurement approaches uniformly suggest that one can only be deemed to be a real patriot if one expresses pride in elements of Germany's national democracy. Conversely, it is assumed that if one is not proud one does not count as patriotic.

Now, turning to nationalism, three major concerns are identified. First, like the measurements of patriotism, a pride item battery was applied to the Ariely model as well as to parts of the model of Fleiß et al. related to the second nationalism factor. However, Miller and Ali (2014) stress that liberal nationalism does not imply pride as a central concept and they voice criticism of this measurement approach based on pride as resulting in a mismatch between the conceptual and the measurement level that deserves further examination. In addition, both scholars measure nationalism by means of pride in history - an obviously very vague term that can be interpreted in many different ways. At this point, it is questionable if this item properly taps the idealisation of one's nation and thus one's history that nationalists are associated with. Further, this item indicates that such glorification holds for both nationalists and liberal nationalists and thus equates the two concepts. However, since the scholars referenced aimed to measure different kinds of nationalism, one would have expected a more nuanced approach here. Given the rather poor factor loading of 0.44 , pride in history does significantly reflect liberal nationalism and has to be reconsidered. In addition, this item highlights the lack of context that the predominant measures suffer from. Due to the Holocaust, Germans are rather cautious about expressing pride in their nation, especially in their history (Miller-Idriss and Rothenberg 2012; Miller and Ali 2014; Meitinger 2018; Assmann 2020). Thus it is reasonable to assume that one can possess nationalistic attitudes and strive for domination over other countries without being proud of Germany's history, as 
expressed in this item. It is noteworthy that the lack of context is further highlighted by the different socialisation and thus divergent collective memories, of Western and Eastern Germans (e.g., Palmowski 2008; Giebler et al. 2020).

Second, upon closer examination, these items are not as clear and unambiguous as they should be to meet the conventional validity requirements. Items such as "Generally, my country is better than most other countries" entail a considerable degree of wariness. The question of which aspect of one's country is assumed to be better in other countries arises here. At this point, one should also take into account this paper's single-case analysis. Given its comparatively high standard of living and the political as well as economic stability, it is doubtless valid to argue that Germany is a better and safer place to live compared with other countries. However, assuming that this statement serves as a proper indicator of nationalism is misleading. If one finds Germany to be a comparatively better country, one is not necessarily a nationalist or a believer in one's nation's superiority.

Third, in terms of content validity, it is reasonable to assume that all the different measurements being used tap only a limited dimension of nationalism and fail to capture constitutive dimensions. For instance, the Davidov model applies only two items that both address belief in one's nation's superiority. Given the broad understanding of nationalism defined by downward comparison with other nations, as well as by the postulate of a nation's homogeneity, all the models lack measurement of important elements. Further, neither is the narrative of threat captured in the measurements. Aside from this, targeting sports or the armed forces highlights the cognitive dimension emphasised in the applied measurements.

Overall, it seems as if pride items are applied here without critically reflecting on the concept itself. First, drawing on the intergroup emotion theory of pride (Smith and Mackie 2015), it remains unclear if the scholars referenced distinguish between pride as a groupbased and as an individual-level emotion. In the current pride measurements, both levels can be triggered and thus the distinction has to be further explored. Second, the premise that pride is a self-conscious emotion that largely hinges on social comparisons (van Osch et al. 2018) challenges the claim that patriotism is rather self-referential and does not imply any comparisons with nationalism (e.g., de Figueiredo and Elkins 2003). Third, the core definition, according to which pride is experienced when "important identity goals" (Tracy 2020:53) are reached, remains unclear in this measurement context. Given that both nationalism and liberal nationalism are measured by the same item, namely pride in history, these identity goals are open to debate. Overall, in future research, the goals that patriots and nationalists are assumed to strive for deserve further scrutiny, especially with regard to the evidenced correlation and thus the contested distinction, between the two concepts. In addition, on a more general note, the question of whether pride is a proper or valid way to approach these concepts has to be raised. For instance, Gilbert and Garcia (2020) assert that patriotism, understood as love of country, does not imply pride as a prerequisite. Here, the distinction between love, affective attachment and pride remains rather vague and has to be further explored, since scholars such as Dekker et al. (2003) contrast national pride with nationalism. Evidently, empirical research on both nationalism and patriotism has largely overlooked the rich field of scholarship on pride and has failed to thoroughly take into account pertinent theories such as the intergroup emotion theory of pride (Smith and Mackie 2015). Put differently, scholars have primarily measured national attitudes via a concept that they have failed to study in a systematic fashion. As a result, a mismatch between the conceptual level and the measurement level is detected. 


\section{Conclusion}

This paper's major goal was to contribute to research on operationalising national attitudes by thoroughly examining how both nationalism and patriotism are measured by Davidov (2009), Fleiß et al. (2009) and Ariely (2011) and how valid the predominant measurement models, in the research tradition of Blank and Schmidt (2003), really are. The way nationalism and patriotism are conceptualised and translated into measurement instruments, i.e., the way the empirical level is reflected in the numerical level, was the key concern in this study. Running a CFA, the models were tested for the German case by also evaluating their measurement invariance for both Eastern and Western Germany.

This study has shown that there is broad agreement on measuring patriotism, since all three models used the same pride scale. In contrast, different but partially overlapping operationalisations were used for nationalism. Overall, the three measurement models yielded satisfying statistical fits and the items reflected both factors pretty well.

The central contribution of this paper lies in highlighting substantial shortcomings regarding the way both nationalism and patriotism are measured. In this sense, three major concerns have been identified. First, the items are marked by a considerable amount of ambiguity, entailing challenges in terms of validity. Second, the models' content validity has to be called into question since constitutive dimensions, especially the emotional, are largely missing for both nationalism and patriotism. In this sense, all the models indicate that patriotism is primarily attached to a sphere of (democratic) rationality and they only tap constitutional patriotism in the Habermasian sense. However, the predominant approach tends to neglect and thus fails to empirically approach, patriotism in the sense traditionally defined as love of country. Third, the prevailing measurement approach is based on an assumption that has remained unquestioned to date. In terms of pride items, one can only be deemed a real patriot or a genuine nationalist if one takes pride in specific national achievements or institutions. Conversely, if one does not take pride in national accomplishments, one is regarded neither as a patriot nor as a nationalist. Due to the prevalent but problematic either/or premise, the measurements are flawed by a simplistic assumption that limits both concepts to the sphere of questionable pride items. Consequently, one can draw the conclusion that the measurement instruments rather tap different kinds of national pride and do not properly measure what they aim to measure. Therefore, the paper calls for more methodological rigour in the way these national attitudes are operationalised.

In light of these shortcomings, this paper closes with two remarks aimed at improving future research. First, it has been shown that scholarship on nationalism and patriotism largely tends to overlook research on pride and consequently draws on a concept without critically reflecting on its true meaning. However, since the predominant measurement models are based on pride item batteries, more account should be taken of research on pride in order to increase the measurements' validity and to disentangle the conceptual and empirical muddiness that current accounts suffer from. For instance, the intergroup emotion theory, dealing with group-based emotions such as national pride, is worth integrating when operationalising these nation-related concepts. At this point, the distinction between authentic and hubristic pride deserves further scrutiny on both conceptual and empirical levels. Examining the relationship between nationalism, patriotism and both kinds of pride seems to be a generative step towards approximating these concepts more closely. Moreover, when testing for measurement invariance, this paper has shown that the models do not hold sufficiently for both Eastern and Western Germany. Due to its context-sensitivity, pride should be treated more cautiously in empirical scholarship. Consequently, drawing 
general conclusions on nationalism or patriotism in Germany as a whole seems to be problematic if differences within the country have not been sufficiently reflected on.

Second, it is worth developing and testing new measurements adhering to concepts other than pride. In this fashion, existing items such as "Generally, Germany is better than other countries" should be replaced by measurements that are less ambiguous in order to fully capture both nationalism and patriotism and to consequently enhance our understanding of how both national attitudes are currently gaining in importance.

Acknowledgements I would like to thank Marco Bitschnau, Bastiaan Bruinsma, Marlene Mauk, Eunike Piwoni and Kristina Simonsen for their valuable comments on an early draft of this paper as well as Peter Schmidt and Horst-Alfred Heinrich for their support. In addition, I am grateful for the feedback of two anonymous reviewers.

Funding Open Access funding enabled and organized by Projekt DEAL.

\section{Declarations}

\section{Conflict of interest None.}

Open Access This article is licensed under a Creative Commons Attribution 4.0 International License, which permits use, sharing, adaptation, distribution and reproduction in any medium or format, as long as you give appropriate credit to the original author(s) and the source, provide a link to the Creative Commons licence, and indicate if changes were made. The images or other third party material in this article are included in the article's Creative Commons licence, unless indicated otherwise in a credit line to the material. If material is not included in the article's Creative Commons licence and your intended use is not permitted by statutory regulation or exceeds the permitted use, you will need to obtain permission directly from the copyright holder. To view a copy of this licence, visit http://creativecommons.org/licenses/by/4.0/.

\section{References}

Ariely, G.: Constitutional patriotism, liberal nationalism and membership in the nation: An empirical assessment. Acta Polit. 46(3), 294-319 (2011)

Assmann, A.: Die Wiedererfindung der Nation. Warum wir sie fürchten und warum wir sie brauchen. C.H. Beck, München (2020)

Bergsieker, H.: National pride and prejudice: The case of Germany. In: Karolewski, I., Suszycki, A. (eds.) Multiplicity of Nationalism in Contemporary Europe, pp. 151-174. Lexington Books, Lanham (2010)

Ben-Porath, S.: Civic virtue out of necessity: Patriotism and democratic education. Theory Res. Educ. 5(1), 41-59

Billig, M.: Banal Nationalism. SAGE, London (1995)

Blank, T.: Gemeinnutz oder Eigenwohl? Motive und Erscheinungsformen nationaler Identität in Deutschland. FRG e.V, Mannheim (2002)

Blank, T., Schmidt, P.: National identity in a united Germany: Nationalism or patriotism? An empirical test with representative data. Pol. Psychol. 24(2), 289-312 (2003)

Bollen, K.: Structural Equations with Latent Variables. Wiley, New York (1989)

Bonikowski, B.: Nationalism in settled times. Annu. Rev. Sociol. 42(1), 427-449 (2016)

Bonikowski, B., di Maggio, P.: Varieties of American popular nationalism. Am Sociolo. Rev. 81(5), 949980 (2016)

Brown, T.: Confirmatory Factor Analysis for Applied Research. Guildford Press, New York (2015)

Brubaker, R.: In the name of the nation: Reflections on nationalism and patriotism. Citizensh Stud. 8(2), 115-127 (2004)

Brubaker, R.: Populism and Nationalism. Nations Natl. 26(1), 44-66 (2020)

Busch, K.: Krise oder Unterstützung der (repräsentativen) Demokratie in Deutschland? Die Entwicklung der letzten zwei Jahrzehnte 1991-2018. ISI. 65, 7-14 (2020)

Chen, F.F.: Sensitivity of goodness of fit Indexes to lack of measurement invariance. Struct Equ Modeling 14(3), 464-504 (2007) 
Choi, S. Y., et al.: National identity can be comprised of more than pride: Evidence from collective memories of Americans and Germans. J Appl Res Memory Cognition (2021). https://doi.org/10.1016/j.jarmac.2020.09.004

Cieciuch, J., Davidov, E., Algesheimer, R., Schmidt, P.: Testing approximate measurement invariance of human values in the European Social Survey. Sociol Methods Res. 47(4), 665-686 (2018)

Citrin, J., Wong, C., Duff, B.: The meaning of American identity. Patterns of ethnic conflict and consensus. In: Ashmore, R., Jussim, J., Wilder, D. (eds.) Social Identity, Intergroup Conflict and Conflict Reduction. Oxford University Press, Oxford (2001)

Cohrs, C., Dimitrova, D., Kalchevska, T., Tomova, I., Vasileva, M., Moschner, B.: Is Patriotic National Pride Desirable? A Differentiated Analysis of Its Psychological Meaning? ZfS 35(4), 201-215 (2004)

Costa, M.: Patriotism and civic virtue. In: M. Sardoč (ed.) Handbook of Patriotism, pp. 213-226. Springer, Cham

Curti, M.: The roots of American loyalty. Columbia University Press, New York, NY (1946)

Davidov, E.: Measurement equivalence of nationalism and constructive patriotism in the ISSP: 34 countries in a comparative perspective. Polit. Anal. 17(1), 64-82 (2009)

Davidov, E., Cieciuch, J., Meulemann, B., Schmidt, P., Algesheimer, R., Hausherr, M.: The comparability of measurements of attitudes toward immigration in the European Social Survey: Exact vs. approximate measurement equivalence. Public Opin. Q. 79, 244-266. (2015)

Dekker, H., Malová, D., Hoogendoorn, S.: Nationalism and Its Explanations. Pol. Psychol. 24(2), 345-376 (2003)

De Figueiredo, R., Elkins, Z.: Are patriots bigots? An inquiry into the vices of in-group pride. Am J Pol Sci. 47(1), 171-188 (2003)

De Lamater, J., Katz, D., Kelman, H.: On the nature of national involvement: A preliminary study. J Conflict Resol. 13(3), 320-357 (1969)

De Vellis, R.: Scale Development. Theory and Applications. Sage, London (2017)

DiStefano, C., McDaniel, H., Zhang, L., Shi, D., Jiang, Z.: Fitting large Factor Analysis models with ordinal data. Educ Psychol Meas. 79(3), 417-436 (2019)

Fabrykant, M.; Magun,V.: Grounded and Normative Dimensions of National Pride in Comparative Perspective. Higher School of Economics Research Paper No. WB BPR/62SOC/2015.ssrn.2599967. (2015)

Feinstein, Y., Bonikowski, B.: Nationalist narratives and anti-immigrant attitudes: Exceptionalism and collective victimhood in contemporary Israel. J. Ethn. Migr. Stud. 47(3), 741-761 (2021)

Fleiß, J., Höllinger, F., Kuzmics, H.: Nationalstolz zwischen Patriotismus und Nationalismus? Berl. J. Soziol. 19(3), 409-434 (2009)

Fukuyama, F.: Identität. Hoffmann und Campe, Hamburg (2018)

Giebler, H., Horvath, S., Weßels, B.: Legitimität der repräsentativen Demokratie in Ost und West. ISI. 65, 3-7 (2020)

Gilbert, M., Garica, I.: On patriotism. In: Sardoč, M. (ed.) Handbook of Patriotism, pp. 271-286. Springer, Cham (2020)

Grimaccia, E., Naccaroto, A.: Confirmatory factor analysis to validate a new measure of food insecurity: perceived and actual constructs. Qual Quant 54(4), 1211-1232 (2020)

Gustavsson, G., Miller; D.: Liberal Nationalism and its Critics: Normative and Empirical Questions. Oxford University Press, Oxford (2019)

Ha, S., Jang, S.-I.: National identity, national pride and happiness: The case of South Korea. Soc. Indic. Res. 121(2), 471-482 (2015)

Habermas, J.: Staatsbürgerschaft und nationale Identität. In: ed. (1992). Faktizität und Geltung. Beiträge zur Diskurstheorie des Rechts und des demokratischen Rechtsstaats. Suhrkamp, Frankfurt (1990)

Hanson, K., O’Dwyer, E.: Patriotism and nationalism, Left and Right: A Q-Methodology study of American national identity. Pol. Psychol. 40(4), 777-795 (2019)

Harrington, D.: Confirmatory Factor Analysis. Oxford University Press, Oxford (2009)

Heinrich, H.-A.: Causal relationship or not? Nationalism, patriotism and anti-immigration attitudes in Germany. Sociology of Race and Ethnicity. 6(1), 76-91 (2020)

Hjerm, M.: National sentiments in Eastern and Western Europe. Nationalities Papers 31(4), 413-429 (2003)

Hroch, M.: The nation as the cradle of nationalism and patriotism. Nations Natl. 26(1), 5-21 (2020)

Hu, L., Bentler, P.M.: Cutoff criteria for fit-indexes in covariance structure analysis: Conventional criteria versus new alternatives. Struct. Equ. Model. 1(1), 1-55 (1999)

Huddy, L., Khatib, N.: American patriotism, national identity and political involvement. Am J Pol Sci. 51(1), 63-77 (2007)

Huddy, L.: Unifying national identity research: Interdisciplinary perspectives. In: Grimm, J., Huddy, L., Schmidt, P., Seethaler, J. (eds.) Dynamics of national identity: Media and societal factors of what we are. Routledge, Abingdon (2016) 
Huddy, L., del Ponte, A., Davies, C.: Nationalism, patriotism and support for the European Union. Pol Psychol. Online First. (2021)

Ignatieff, M.: Blood \& Belonging: Journeys into the New Nationalism. BBC Books, London (1993)

Ingram, A.: Constitutional patriotism. Philosophy \& Social. Criticism 22(6), 1-18 (1996)

Karasawa, M.: Patriotism, nationalism and internationalism among Japanese citizens: An Etic- Emic approach. Pol. Psychol. 23(4), 645-666 (2002)

Kohn, H.: The Idea of Nationalism. Macmillan, New York (1944)

Kosterman, R., Feshbach, S.: Toward a measure of patriotic and nationalistic attitudes. Pol. Psychol. 10(2), 257-274 (1989)

Kronenberg, V.: Patriotismus in Deutschland: Perspektiven für eine weltoffene Nation. VS, Wiesbaden (2013)

Laborde, C.: From constitutional to civic patriotism. Br. J. Pol. Sc. 32(4), 595-612 (2002)

Laborde, C., Erez, L.: Cosmopolitan patriotism as a civic ideal. Am J Pol Sci. 64(1), 191-203 (2020)

Langewiesche, D.: Nation, Nationalismus. Nationalstaat in Deutschland und Europa. C.H. Beck, München (2002)

Latcheva, R.: Cognitive interviewing and factor-analytic techniques: A mixed-method approach to validity of survey items measuring national identity. Qual Quant. 45(6), 1174-1199 (2011)

Levinson, D.J., Adorno, T.W., Frenkel-Brunswik, E., Sanford, R.N.: The Authoritarian Personality. Harper, New York (1950)

Li, Q., Brewer, M.: What does it mean to be an American? Patriotism, nationalism and American identity after September 11. Pol. Psychol. 25(5), 727-739 (2004)

Liu, Y., Millsap, R., West, S., Tein, J., Tanka, R., Grimm, K.: Testing measurement invariance in longitudinal data with ordered-categorical measures. Psychol. Methods 22(3), 486-506 (2017)

MacIntyre, A.: 'Is patriotism a virtue?' In R. Beiner (ed.), Theorizing citizenship. Albany, NY: State University of New York Press (1995)

Mader, M.: Stabilität und Wandel der nationalen Identität in der deutschen Bevölkerung. Kolner Z Soz Sozpsychol. 68, 435-456 (2016)

Meitinger, K.: What does the general national pride item measure? Insights from web probing. Int J Comp Sociol. 59(5), 428-450 (2018)

Miller, D., Sundas, A.: Testing the national identity argument. Eur Pol Sci Rev. 6(2), 237-259 (2014)

Miller-Idriss, C., Rothenberg, B.: Ambivalence, pride and shame: Conceptualisations of German nationhood. Nations Natl. 18(1), 132-155 (2012)

Miller, D.: On Nationality. Oxford University Press, Oxford (1995)

Molina, L., Philipps, N., Sidanius, J.: National and ethnic identity in the face of discrimination: Ethnic minority and majority perspectives. Cultur. Divers. Ethnic Minor. Psychol. 21(2), 225-236 (2015)

Molina, L., Preddie, J.: Threatening others: National identity and group threats predict immigration policy. Anal. Soc. Issues Public Policy 20(1), 417-442 (2020)

Mounk, Y.: The People vs. Democracy: Why Our Freedom Is in Danger and How to Save It. Harvard University Press, Cambridge, MA (2018)

Müller, J.-W.: Verfassungspatriotismus. Suhrkamp, Berlin (2010)

Mummendy, A., Klink, A., Brown, R.: Nationalism and patriotism: National identification and outgroup rejection. Br. J. Soc. Psychol. 40(2), 159-172 (2001)

Mylonas, H:, Tudor, M.: Nationalism: What we know and what we still need to know. Annu. Rev. Political Sci. 24:109-32 (2021)

Nathanson, S.: Moderate patriotism. In: Sardoč, M. (ed.) Handbook of Patriotism, pp. 141-161. Springer, Switzerland (2020)

Osborne, D., Milojev, P., Sibley, C.: Authoritarianism and national identity: Examining the longitudinal effects of SDO and RWA on nationalism and patriotism. Personality and Social Psychological Bulletin. 43(8), 1086-1099 (2017)

Palmowski, J.: Citizenship, identity and community in the German Democratic Republic. In: Eley, G., Palmowski, J. (eds.) Citizenship and National Identity in Twentieth-Century Germany. Stanford University Press, Stanford (2008)

Primoratz, I.: Patriotism. In: Zalta, E.N. (ed.) Stanford Encyclopedia of Philosophy. https:// plato.stanford.edu/archives/sum2017/entries/patriotism/ 2017. Accessed 26 January 2021

Sapountzis, A.: Towards a critical social psychological account of national sentiments: Patriotism and nationalism revisited. Soc Personal Psychol Compass. 2(1), 34-50 (2008)

Satherly, N., Yogeeswaran, K., Osborne, D., Sibley, C.: Differentiating between pure patriots and nationalistic patriots: A model of national attachment profiles and their socio-political attitudes. Int $\mathrm{J}$ Intercult Rel. 72(1), 13-24 (2019) 
Schatz, R., Staub, E., Lavine, H.: On the varieties of national attachment: Blind versus constructive patriotism. Pol. Psychol. 20(1), 151-172 (1999)

Schildkraut, D.: Boundaries of American identity: Evolving understandings of “us.” Annu. Rev. Pol. Sci. 17(1), 441-460 (2014)

Sidanius, J., Feshbach, S., Levin, S., Pratto, F.: The interface between ethnic and national attachment. Ethnic pluralism or ethnic dominance? Public Opinion Quarterly 61: 102-133 (1997)

Simonsen, K., Bonikowski, B.: Is civic nationalism necessarily inclusive? Conceptions of nationhood and anti-Muslim attitudes in Europe. Eur J Pol Res. 59(1), 114-136 (2020)

Smith, E., Mackie, D.: Dynamics of group-based emotions: Insights from intergroup emotions theory. Emot. Rev. 7(4), 349-354 (2015)

Sternberger, D.: Schriften: X: Verfassungspatriotismus. Insel, Frankfurt (1990) Tamir, Y.: Liberal Nationalism. Princeton University Press, Princeton, NJ (1993)

Tamir, Y.: Why Nationalism. Princeton University Press, Princeton, NJ (2019)

Tracy, J., Mercadante, E., Witkower, Z., Cheng, J.: The evolution of pride and social hierarchy. Adv Exp Soc Psychol. 62, 51-114 (2020)

Tracy, J., Robins, R.: The nature of pride. In: Tracy, J., Robins, R., Tangney, J. (eds.) The Self- Conscious Emotions: Theory and Research, pp. 263-282. Guildford Press, London (2007)

van Osch, Y., Zeelenberg, M., Breugelmans, S.: The self and others in the experience of pride. Cogn. Emot. 32(2), 404-413 (2018)

Wagner, U., Becker, J., Christ, O., Pettigrew, T., Schmidt, P.: A longitudinal test of the relation between German nationalism, patriotism and outgroup derogation. Eur Sociol Rev. 28(5), 319-332 (2012)

Wessel, J.: Nationen Und Nationalismus. Neue Polit. Lit. 64(1), 81-104 (2019)

Wimmer, A., Glick Schiller, N.: Methodological nationalism and the study of migration. Eur J Sociol. 43(3), 217-240 (2002)

Wimmer, A.: Nation Building: Why Some Countries Come Together While Others Fall Apart. Princeton University Press, Princeton, NJ (2018)

Publisher's Note Springer Nature remains neutral with regard to jurisdictional claims in published maps and institutional affiliations. 